\title{
Malta's EU Membership: Chapter 1 Concluded, Chapter 2 Just Started
}

\author{
RODERICK PACE
}

In May 2004 Malta joins the European Union. In the attainment of this goal Malta has experienced the most dramatic passage to membership. In July 1990 it applied for membership; in 1996 it suspended the application, only to revive it in 1998. It caught up with the other candidate countries to be the first to hold a referendum on membership, obtaining a positive result despite the extreme polarization of Maltese society over the issue. Indeed it was the first among the candidate countries to ratify the Accession Treaty. With one of the highest participation rates in politics in the world, characterized by competition between two political parties of more or less equal strength (the governing Nationalist Party - NP - and the opposition Malta Labour Party - MLP), an important issue such as EU membership was bound to become highly charged. On average 96 per cent of eligible voters participate in Maltese general elections, which are normally held every five years. All political issues tend to be intensely debated in the Maltese 'polis' and the electorate is a highly mobilized one by most standards. Undeniably, since 1987 the EU membership issue has dominated the Maltese political debate as few other issues have done before. Commentators have compared the intensity of this debate to three other highly contentious issues which preceded it in Malta's post-war history: the debate on the proposal to integrate Malta with the United Kingdom (1955-58), the independence issue (1962-64) and the crisis over majority rule (1981-87).

EU membership was decided favourably in a referendum held on 8 March 2003 and then in a general election held on 12 April 2003. In the referendum, 270,650 out of 297,881 (90.85 per cent) registered voters cast their votes, of whom 52.87 per cent voted in favour of EU membership

Roderick Pace is Director and Lecturer in International Relations and European Studies at the European Documentation and Research Centre (EDRC) of the University of Malta.

Mediterranean Politics, Vol.9, No.1 (Spring 2004), pp.114-121 
while 45.67 per cent voted against and 1.45 per cent invalidated their vote. The MLP had campaigned strongly against membership and in favour of a free trade 'partnership' agreement with the EU. It refused to recognize the result and, in keeping with its long-stated position that the issue had to be decided in a general election, voters were called to the polls again on 12 April. This time a majority of just below 52 per cent voted to return the incumbent NP to government. The NP had unequivocally favoured Malta's EU membership since 1979. Just a couple of days after the publication of the general election result and after taking the oath of office, Malta's prime minister Eddie Fenech Adami went to Athens on 16 April to sign the treaty of accession.

The signing of the Athens agreement signified the closure of one chapter in Malta's recent political history and the opening of a new one. The focus shifted to the Labour Party. Following a brief leadership 'crisis' that saw the unexpected reconfirmation of the party's incumbent leader Alfred Sant, the party began a painful internal debate on its EU policy. The signs of change came in quick succession. Immediately after the election, a couple of freshly re-elected Labour members of parliament declared that EU membership was no longer an issue. Then in an interview to the Malta Independent on Sunday of 1 June 2003, Sant said: 'What we believe about EU accession is now immaterial. The thing has been decided and we face a new reality now. This is not a question of changing our minds but of accepting reality.' Since the MLP had constantly argued that membership should be decided by a general election, the party was able to justify its change of policy on the grounds that it was bowing to the democratic will of the majority. Comparisons with the UK Labour Party and the Greek Socialist Party PASOK were also made in defence of this turnaround. However, it was also true that while both the UK Labour Party and PASOK had taken more time to change their positions on the EU, Maltese Labourites were being asked to make the change in just a few months. This was largely dictated by the need to prepare the party for the European Parliament elections due in June 2004.

This change of policy by the MLP was helped by the existence of a sizeable minority in favour of EU membership within the party. This silent faction had for many years been a reluctant passenger in the party's intense anti-EU membership crusade. In the post-election phase, it was somewhat hamstrung by the reconfirmation of Sant as party leader, whom many blamed for the referendum and election debacle. Indeed, a change of party leader would have facilitated the party's change of direction on the EU. On the other hand, Sant's new pragmatism on the EU was opposed by Karmenu Mifsud Bonnici, a former prime minister and leader of the MLP, and founder of the Campaign for National Independence (CNI) established soon 
after the commencement of the membership negotiations with the EU, to campaign against membership. Mifsud Bonnici later abandoned CNI to join Dom Mintoff, another former leader of the MLP and twice prime minister (1955-58, 1971-85), at the head of a new organization, the Front Maltin Inqumu (Maltese Arise Front). Mintoff had caused a furore in 1998 when he brought down the Labour government of Sant by voting against it in a vote of confidence in the House of Representatives. That vote led to an early election that saw the Nationalist Party returned to government with a comfortable five-seat majority, ironically opening the way to the resumption of membership negotiations with the EU.

The MLP called a general conference to be convened between 7 and 9 November to discuss and approve a motion, which amongst other things called on the party to accept EU membership. At the same time it started mending its fences with the Party of European Socialists (PES) from whom it had strayed. The internal 'No' faction headed by Mifsud Bonnici presented a different motion urging the party to remain consistent with its pre-election anti-EU policy and to 'work incessantly' to change the EU membership agreement, a euphemism for negotiating Malta's exit from the Union at the first available opportunity. The two motions were to be voted on separately, raising the ominous prospect that both would be approved by the party delegates in a bid to maintain unity despite their mutual exclusiveness. In a last minute compromise, Mifsud Bonnici withdrew his motion in return for an addition to the wording of the motion calling on the party:

in opposition and in government to do its utmost with all means and within the realm of the possibilities available, to counter all the negative effects that could result from the membership agreement reached by the Nationalist Government and to see that this agreement is not disadvantageous to the Maltese people...

Mifsud Bonnici's original amendment, which he later withdrew, had made no reference to 'countering the negative effects' but more specifically to 'changing the membership package', spelling the danger that Labour's dual personality on Europe could linger on for some time into the future, notwithstanding the impression that the matter had been closed for good by the conference. When the amended motion was put to the vote, 647 delegates voted for it, 17 voted against, two votes were invalidated and two delegates abstained. Thus a staggering 96.9 per cent of the party delegates approved the change of policy. However, it is necessary to point out that in the election of the party officials a couple of days earlier, no fewer than 871 votes were cast, indicating that 203 voters stayed away from the crucial vote on the EU motion. 
Apart from finally deciding Malta's EU fate and changing the MLP's stance on the EU, the 2003 referendum and general election were significant for a few additional reasons. First, they confirmed that, as successive opinion polls had indicated in the years before the referendum, the Maltese electorate was closely divided over membership. The same surveys had constantly shown that those in favour of membership had a slight advantage over those against. All this was in line with past historical experience: in all the general elections since 1966, all dominated by the MLP-NP 'duopoly', the party winning the election normally secured slightly less than 52 per cent of the valid votes cast. Significantly also, during the campaign some speculators argued that a substantive part of the electorate might be ready to ditch the Nationalist Party in the election given that it had been in government for all the years since 1987 except for a brief 22-month period in 1996-98. This of course did not materialize and might be indicative of the solidity of the pro-EU constituency in Malta, which the MLP may have overlooked. Indeed, in an opinion poll carried out on behalf of the Sunday Times of Malta (the biggest circulation newspaper in the country) and published on 1 June 2003, 81.3 per cent of respondents wanted the MLP to embrace EU membership. This also indicated that support for EU membership runs deeper than the election and referendum results show and cuts much deeper across party lines. Also, many who voted 'No' in the referendum and for the MLP in the election may have done so more out of loyalty to the party than out of conviction concerning its EU membership policy. Lastly, 2003 saw Malta transformed from a deeply polarized country regarding EU membership, to one where support for membership is very similar to that encountered in other southern European countries. In addition, the MLP's decision to follow in the footsteps of its Greek and UK counterparts, by changing its policy on Europe, has not only strengthened Maltese support for EU membership but also changed the competitive nature of Maltese politics. Officially the curtain was brought down on the MLP's anti-EU stance on 14 November, when the PES unanimously accepted the MLP as a full member.

\section{The Position of the Governing Nationalist Party}

The NP's pro-EU stance often confounds those political observers who are unfamiliar with Maltese politics. How can nationalism and European integration be reconciled? One plausible explanation is that Maltese nationalism has been historically defined by the necessity of acquiring independence and statehood, while encouraging Malta's efforts to join the European mainstream. In 1962 Malta under a Nationalist government requested independence from the UK. But since the UK had already asked 
to join the EEC, it became clear that given its economic dependence on the UK, it was important for Malta to conclude some form of trade arrangement with the Community in the event that the UK joined it. In subsequent years this position was refined further; on his way to a conference of Commonwealth prime ministers convened in London in September 1962 to discuss the UK's EEC membership, Malta's prime minister expressed this change quite succinctly:

We have expressed our wish that Malta joins the European Community, though we still do not have a formal application. We believe that eventually, Malta will join the Community, both in the event of the UK's membership and not. We too form part of Europe. Since Malta is still not independent, it can only apply for an Association Agreement. We are hoping to gain independence in a short while. In that way we will be able to ask for full membership. [However] Malta will not make a formal application before examining the problems which the UK will face in its own application. ${ }^{2}$

Later, the European Commission proposed an interim and sui generis agreement for Malta, which would apply in the event that the UK joined the Community before Malta had become independent. In 1967, three years after independence, Malta again approached the EEC for the conclusion of some form of agreement. This culminated in the signing of an association agreement in 1970 envisaging the eventual establishment of a customs union with the Community at the end of a second stage. No reference to eventual Community membership was made in the agreement, but both sides seemed to regard it as a preparatory stage to membership. Prime minister Borg Olivier, in a speech on the occasion of the signing of the agreement, said 'We are also hopeful that in the course of time it could develop into fuller participation in a united Europe ${ }^{33}$ Sigismund von Braun, permanent representative of Germany, who at the time held the presidency of the Council, replied:

The Community is aware of the fact, that, in seeking association with it, Malta has made a choice which goes beyond the mere settlement of economic matters ... The Maltese Government has in fact decided on the close participation of the country in the work of European integration ... This agreement is in fact a starting point, not an achieved goal. ${ }^{4}$

The agreement was criticized by the MLP led by Dom Mintoff and when it was elected to government in 1971 negotiations with the EEC led to the broadening of its scope by means of additional protocols concluded 
in the mid-1970s, in line with the EC's new Global Mediterranean Policy. In 1979, in the wake of the EC's second enlargement and just prior to the closure of the British military bases in Malta, the NP launched its EU membership policy. The party was only able to begin to pursue this aim when it was elected to government in 1987. In 1990 Malta applied to join the EU.

\section{Main Results of Membership Negotiations}

In the membership negotiations, Malta successfully employed its small size to secure concessions that would meet the salient concerns of the Maltese electorate, the unique characteristics of smallness as well as Malta's economic and political exigencies. The political divisiveness of membership discussed above may actually have helped Malta in attaining these goals. The main outcomes of the negotiations from a Maltese perspective are:

- Malta did not need to abandon its neutrality, closely defined in its Constitution. This step would have required the approval of two-thirds of the House of Representatives. Malta made a Declaration, attached to the Treaty of Accession (TA, OJ L 236, 23 September 2003), whereby it affirmed its commitment to the Common Foreign and Security Policy, while stressing that any decision to move to a common defence would have to be taken by unanimity by the Council and that it had to be adopted by the member states in accordance with their constitutional requirements.

- The Maltese language, which has developed from Arabic and is spoken by the majority of Maltese, was accepted as an official EU language.

- Protocol No.7 attached to the TA declared: 'Nothing in the Treaty on European Union, or in the Treaties establishing the European Communities, or in the Treaties or Acts modifying or supplementing those Treaties, shall affect the application in the territory of Malta of national legislation relating to abortion.' In predominantly Catholic Malta, abortion is not permitted and there is a solid anti-abortion majority that crosses political party lines.

- Protocol No.6 allows Malta to regulate and retain certain restrictions on the freedom of non-nationals to acquire property as a secondary residence unless they have legally resided in Malta for a period of five years. Malta is obliged to publish transparent and non-discriminatory criteria to regulate the acquisition of secondary properties, but is permitted to revise the value thresholds to reflect changes in property prices in Malta. This measure was dictated by Malta's restricted 
territorial size $\left(316 \mathrm{~km}^{2}\right)$ and its high population density, which at 1,911 persons per $\mathrm{km}^{2}$ is the second highest in the world.

- Maltese citizens will enjoy complete free movement in the rest of the EU upon accession (Article 39). Malta has however secured a seven-year transitional arrangement in which it may call upon the Commission to restrict within a period of two weeks the right of EU citizens to seek employment in Malta. Malta may also take similar action unilaterally in urgent and exceptional cases and send a reasoned ex-post notification to the Commission. This safeguard has been negotiated given that a small influx of workers from the EU may create serious problems in Malta's small labour market. A declaration by the current member states was also attached to the TA.

- On value added tax (VAT), Malta accepted a transitional period until 1 January 2010 up to which it can maintain its zero per cent rate instead of the standard five per cent on supplies of foodstuffs and pharmaceuticals provided that the transitional period referred to in Article 28(1) of the Sixth VAT Directive would expire on that day (TA; OJL 236, Declaration 37, p.983).

- A declaration by Malta on the sister island of Gozo (population circa 35,000 ) notes the economic and social specificities and disadvantages of the island, proposing measures to overcome them such as the zero-rating of inter-island transport and transitional arrangements for the transport of agricultural goods to Malta. The declaration goes on:

before the end of each Community budgetary period entailing a redefinition of the Community regional policy, Malta will request that the Commission report to Council on the economic and social situation of Gozo and in particular on the disparities in the social and economic development levels between Gozo and Malta.

The Community would be asked to adopt the necessary measures under the regional policy or other Community instruments to reduce such disparities.

- Malta has secured an amendment to Regulation EC 1626/94 by which it will manage a 25 nautical mile conservation zone in which fishing effort will be limited to small-scale coastal fishing, a measure that helps preserve the small Maltese fishing sector, while ensuring that fish stocks in this area are not wiped out by more aggressive fishing methods used by fishermen from other EU states.

- On agriculture, Malta has been allowed to operate a unique Special Market Policy Programme for Maltese Agriculture, which is a system of temporary state aid to support agricultural producers up to a specified 
ceiling of output relevant to each sector constituting Malta's key agricultural products.

\section{Conclusion}

It has not been possible in the context of this Profile to provide a comprehensive analysis of Malta's EU membership bid and the main implications of membership. However, it has been shown that the EU membership issue, having split Maltese society down the middle for many years following the application made in 1990, seems now to have been resolved. This does not mean that the debate is closed forever; it simply means that one chapter has been closed and another has just begun to be written. The main characteristics of this new phase are no longer whether Malta should join the EU or not, but about how the country will perform within the Union. The new-found unity augurs well for the Maltese in the EU. Yet if the political struggle and divisiveness is now going to be transposed to another level, it may not only provide more grist to the political scientist's mill, but may also sap some of the scarce resources of this small member state.

\section{NOTES}

1. http://www.mlp.org.mt/stqarrijiet/full_report.asp?ContentID=STQ031107c (19 Nov. 2003).

2. Quoted in 'Ir-Review', Department of Information, Malta, Sept. 1962.

3. Ibid., p.5.

4. Malta Today, V, No.12, Dec. 1970, Department of Information, Malta, p.4. 